\title{
A Review of Task-based Language Teaching
}

\author{
Shuguang Zhang \\ School of Foreign Languages, Chifeng University, Chifeng, Inner Mongolia, China \\ 05012311@163.com
}

Keywords: Task; Feature; Task-based language teaching

\begin{abstract}
The construct of task has become so universal as to turn it into one of the best-validated terms in second language acquisition (SLA). Task has become the fulfillment of an evolving disciplinary agreement with an emphasis on meaning. Both teachers and students have been aware of linguistic form in language pedagogy, interaction and in the methodology of task-based language teaching. Task-based teaching is considered as an effective way to draw students' attention to form, function and meaning. These ideas have been categorized below to establish the issues, to describe the definitions of tasks, to illustrate the criteria features of tasks, and to discuss the implementation of task-based language teaching.
\end{abstract}

\section{Definition of Tasks}

In term of definitions of tasks, we find that the term has been defined in a variety of ways in general education, from within the field of second language teaching, to other fields for pedagogic and psycholinguistic reasons. There is now a general consensus that the task is meaning-focused rather than form-focused [1, 2, 3, 4].

Long [1] defined task as "a piece of work undertaken for oneself or for others, freely or for some reward", and it means "the hundred and one things people do in everyday life, at work, at play, or in between". This definition is non-technical and non-linguistic. In fact, it describes the sorts of things that non-linguists would tell you they do if they were to be asked.

Richards, Platt and Weber [2] take tasks from a pedagogical perspective. A task is "an activity or action which is carried out as the result of processing or understanding language". The use of tasks in language teaching is to "make language teaching more communicative". Tasks are defined in terms of what the learner will do in the classroom rather than in the outside world.

Breen [3] circumscribes task as "any structured language learning endeavor which has a particular objective, appropriate content, a specified working procedure, and a range of outcomes for those who undertake the task". He implies that tasks involve communicative language use in which the learners' attention is focused on meaning instead of linguistic structure. Similarly, Long mentions filling out a form, making an airline reservation, etc; Richards et al. refer to drawing a map, and listening to an instruction and carrying out a command, which shares the same implications with Breen.

In similar fashion, Nunan [4] considers the communicative task as "a piece of classroom work which involves learners in comprehending, manipulating, producing or interacting in the target language". In similar fashion, he emphasizes that the learners' attention is principally focused on meaning rather than form. What's more, he claims that the task should have a sense of completeness, being able to stand alone as a communicative act in its own right with a beginning, a middle and an end.

In this article, I prefer that a task is an activity that learners engage in to further the process of learning a language. 


\section{Criteria Features of a Task}

It is important to tell from what is a task and what is not. Tasks do not give other people's meaning to regurgitate; Tasks are not concerned with language display; Tasks are not conformity-oriented; Tasks are not practice-oriented; Tasks do not embed language into materials so that specific structures can be focused upon. So what are the criteria features of a task?

According to Gong [5], we can know the communicative tasks have four features. Firstly, meaning is primary. Secondly, there are some communicative issues to solve which has some sort of relationship to comparable real-world activities. Thirdly, task completion has some priority. Finally, the assessment of the task is in terms of outcome.

Ellis [6] gives us six criteria features. A task is a work plan for learner activity. A task involves a primary focus on meaning. A task involves real-world processes of language use. A task can involve any of the four language skills. A task engages cognitive processes such as selecting, classifying, ordering, and evaluating information in order to carry out the task. A task has a clear defined communicative outcome.

According to above illustration, there are some features in common. Tasks, with an emphasis on completion, are meaning-focused and to solve some communicative issues which closely relate to the real world.

\section{Tasks in Foreign Language Teaching}

Task Components. According to Candlin [7], tasks contain seven components: input, roles, feedback, actions, monitoring, outcomes and Settings. Input refers to the data presented for learners to work on. Roles specify the relationship between participants in a task. Settings refer to the classroom and out-of-class arrangements entailed in the task. Actions are the procedures and sub-tasks to be performed by the learners. Monitoring refers to the supervision of the task in progress. Outcomes are the goals of the task, and feedback refers to the evaluation of the task.

Shavelson and Stein [8], who are concerned with general educational planning of instrumental tasks, suggest that task design should consider the following six elements: content, materials, activities, goals, students and social community. Content refers to the subject matter to be taught. Materials involve those things the learner will observe or manipulate. The activities are the things the teacher and the learners will be carrying out. The goals deal with the teachers' general aim for the task. The abilities, needs and interests of the students and the social and cultural context of instruction have close relationship with the last two elements. The list is so comprehensive that with a little rearrangement, and the addition of assessment and evaluation components, it could form the basis for a comprehensive curriculum model.

Wright [9] considers that tasks need minimally contain just two elements. These are input data which may be provided by materials, teachers or learners and an initiating question which instructs learners on what to do with the data. He rejects the notion that objectives or outcomes are obligatory on the grounds that, with certain tasks, a variety of outcomes might be possible and that these might be quite different from the ones anticipated by the teacher.

Nunan [4] views tasks as consisting of six elements. They are goals, input, output, roles of teachers, roles of learners and a setting. Goals are the indistinct general intentions behind any given language task, which may relate to a range of general outcomes or may directly describe teacher or learner behaviors. Input refers to the data that form the point of departure for the task while activities are what the learners do with the input. He also claims that these elements inevitably influence one another in a dynamic and interactive way.

A different perspective on the elements that form a task is provided by Legutke and Thomas [10], who views tasks principally as a part of an interactive process whose rationale lies within a social and an educational framework. They identify three major elements in an interactive process, which are the 
individual, the group, the theme. These keep a dynamic balance in what they call theme-centered interaction. Similar to Nunan, they both emphasize on the interactive and dynamic nature of tasks and include the teachers' contributions. However, neither gives us any particulars as to how teachers carry out different roles and how they act as mediators in designing or presenting tasks to learners.

According to Jack C. Richards, John Platt and Heidi Platt [11], task is "an activity which is designed to help achieve a particular learning goal". A number of dimensions of tasks influence their use in language teaching. They include goals, procedures, order, pacing, product, learning strategy, assessment, participation and resources. Goals refer to the kind of goals teachers and learners identify for a task. Procedures are the operations or procedures learners use to complete a task. Order is the location of a task within a sequence of other tasks. Pacing refers to the amount of time that is spent in a task. Product means the outcome or outcomes students produce, such as a set of questions, an essay, or a summary as the outcome of a reading task. Learning strategy is the kind of strategy a student uses when completing a task. Assessment refers to how success on a task will be determined. Participation is whether the task is completed individually, with a partner, or with a group of other learners. Resources are the materials and other resources used with a task.

Though from quite different perspectives, what they have in common is that a task at least consists of goals, input and output while most of them speak of the roles of teachers and learners play.

Factors of Ranking Tasks and Task Difficulty. It is generally believed that difficulty is the key factor in determining the ordering of items in the designing and completing the tasks. All things being equal, items are presented to learners according to their degree of difficulty. However, the grading of tasks is a particularly complex issue because of the many diverse elements that contribute to task difficulty, all of which overlap and influence each other. In addition, as some of these factors will be dependent on learners' characteristics, what is difficult for this learner may not necessarily be difficult for that one.

Richards, Platt and Weber [2] have described grading in the following way: (It is) the arrangement of the content of a language course or a textbook so that it is presented in a helpful way. Graduation would affect the order in which words, word meanings, tenses, structures, topics, functions, skills, etc. are presented. Graduation may be based on the complexity of an item, its frequency in written or spoken English, or its importance for the learner.

Nunan [4] consider factors in relation to the various components in his model of task. He first gives us the input factors of grading tasks and task difficulty from nine aspects: the grammatical complexity of the text; the length of the text; the propositional density; the vocabulary used; the speed of listening text; the number of speakers involved; the explicitness of the information; the genre, discourse structure and sequencing of items in the text as well as the amount of support in the form of pictures. Then he gives us output and other factors, which are not elaborated here one after another.

According to Prabhu [12], the factors of grading tasks and task difficulty include the amount and type of information provided; the amount of reasoning or cognitive operation needed; the precision needed; the learners' knowledge of the world \& familiarity and with the purposes and constraints of the task as well as the degree of abstractness of the concepts dealt with in the task.

Candlin [7] offers a taxonomy which focuses solely on the nature of task. He identifies the factors of grading tasks and task difficulty as the following: cognitive complexity; communicative difficulty; whether the task follows a general sequence of operations or whether this is unclear; Linguistic complexity and continuity between tasks.

Bindley [13] suggests that the difficulty is determined by the following factors: relevance to the learner; complexity; amount of context provided and knowledge of the world required; Language demands; Assistance given; Accuracy required and time available.

Different people have different opinions about grading tasks and task difficulty. When we face a specific task we must consider it accordingly. 


\section{Implementation of Task-based Teaching}

Task-based teaching is a form of communicative teaching rationale. It converts the basic rationale of language application into practical classroom teaching methods. Foreign language teaching is a complex process. In fact, no a single teaching methodology respectively works well. What the teacher taught in class doesn't necessarily be learnt by the learners. Teachers' role is to create an enabling condition beneficial for the learners. Teaching syllabus is on what to learn while teaching methodology is on how to learn, so they should integrate with each other.

Task-based teaching [14] can be seen as the development beyond Prabhu of the task-based syllabus idea. Task-based teaching has become a subject of keen contemporary interest, and different task-based approaches exist today. Some differ substantially from Prabhu's, often not being so certainly on the parallel with L1 acquisition. But one underlying principle holds for all the approaches - to place the emphasis firmly on activities or tasks that learners do in class. This emphasis is reflected in much current research which studies the characteristics of different sorts of activities. It is possible that the late 1990s will be known as in applied linguistics "the Age of Task".

One particular task-based teaching is related to the ideas about Language learning, skill acquisition and automization. The ra-1(required attention minus one) was introduced. According to this formula, focus on form is progressively reduced, by developing tasks that in various ways take up more or less of the learner's attention, until $\mathrm{ra}=0$, the point where full automization is achieved.

Carless, David and R. Factors [15] offer us some factors that Influence task-based teaching: Teacher beliefs, teacher understandings, the syllabus, time available, the textbook and the topic, preparation and the available resources and the language proficiency of the students.

The Emphasis of task-based teaching [16] is on the interaction in the target language, authentic texts, opportunities to focus on the learning process, learners' personal experiences in classroom learning and linking classroom learning to language outside of the classroom.

The design of a task-based lesson involves consideration of the stages or components of a lesson that has a task as its principal component. Various designs have been proposed. However, they all have in common three principal phases. These phases reflect the time order of a task-based lesson. Thus, the first phase is 'pre-task' and concerns the various activities that teachers and students can undertake before they start the task, such as whether students are given time to plan the performance of the task. The second phase, the 'during task' phase, focus on the task itself and affords various instructional options, including whether students are required to operate under time-pressure or not. The final phase is 'post-task' and involves procedures for following-up on the task performance. Only the 'during task' phase is a must in task-based teaching. Thus, minimally, a task-based lesson consists of the students just performing a task. Options selected from the 'pre-task' or 'post-task' phases are non-obligatory but, as we will see, can serve an important role in ensuring that the task performance is highly effective for language development.

In my understanding, task-based teaching is not primarily a language-teaching approach. It is mainly concerned with improving learners' command of what they know---what we used to name as fluency practice, that is, to make full use of their own linguistic resources. Through the interaction between the teachers and learners, a task can be fulfilled successfully.

\section{Conclusion}

Tasks involve input, activities and cognitive operations. We'd better consider tasks with other variables within the teaching-learning process. Tasks are normally designed or selected by teachers to achieve some purposes which reflect their implicit views about learning and education. These tasks or activities can vary in different ways which will reflect different educational views. The selected task will be carried out by learners who will employ a range of cognitive and social processes to make sense of an 
attempt to complete them. The task also arouses a range of feelings and emotions on the part of the learners, which will affect the ways in which they make sense of and carry out the activities.

As a teaching method, task-based teaching itself is not the unique and the most effective one in the teaching-learning process. Every single teaching method has its existing conditions and soil. Consequently, teaching method is just a useful way for teachers to help learners achieve their purposes if possible. Whether the task-based teaching is helpful or not, it depends on many factors. We cannot say which method is the best, but which one is the appropriate one when considering every conceivable other variable and specific conditions. However, other factors being equal, task-based teaching method is undoubtedly feasible and practical.

\section{References}

[1] Long, M: A role for instruction in second language acquisition. In K. Hyltenstam and M. Pienemann (Eds.) Modeling and Assessing second Language Acquisition (Multilingual Matters, U.K 1985), p.89.

[2] Richards J., J. Platt and H. Weber: Longman Dictionary of Applied Linguistics (Longman, England 1986), p.289.

[3] Breen, M: Learner contributions to task design. In C. Candlin and D. Murphy (Eds.) Language Learning Tasks (Prentice-Hall, America, 1987), p.23.

[4] Nunan, D: Designing Tasks for the Communicative Classroom (Cambridge University Press, England 1989), p.10.

[5] 龚亚夫：任务型语言教学 (人民教育出版社, 中国 2003). (In Chinese)

[6] Ellis, Rod: Task-Based Language Learning and Teaching (Oxford University Press, America 2003).

[7] Candlin, C: Towards task-based language learning. In C. Candlin and D. Murphy (eds.). Language Learning Tasks (Prentice Hall International, America 1987).

[8] Shavelson, R. J., and Stein, P: Research on teachers' pedagogical thoughts, judgements, decisions and behaviour. Review of Educational Research, Vol. 51 (1981) No.6, p. 455-498.

[9] Wright, T: Instructional task and discoursal outcome in the L2 classroom. In C. Candlin and D. Murphy (Eds.) Language Learning Tasks (Prentice-Hall, America, 1987).

[10]Legutke, M., and H.Thomas: Process and Experience in the Language Classroom (Longman, England 1991).

[11]Richards, Jack C. Platt, John and Heidi Platt: Longman Dictionary of Language Teaching and Applied Linguistics (Beijing Foreign Language Teaching and Research Press, China 2000), p.468.

[12]Prabhu, N.S: Second Language Pedagogy (Oxford Oxford University Press, England 1987).

[13]Brindley,G: Factors affecting task difficulty. In Nunan, D (Eds.) Guidelines for the Development of Curriculum Resources (National Curriculum Resource Centre, Austrilia 1987b).

[14]Johnson, keith: An Introduction to Foreign Language Learning and Teaching (Beijing Foreign Language Teaching and Research Press, China 2002).

[15]Carless, David, R: Factors in the Implementation of Task-based Teaching in Primary School. System Direct, Vol. 31 (2003) No.4, p.485-500.

[16]Nunan, D: Task-based Syllabus Design (Multilingual Matters, New Zealand 1991). 